\title{
Inventorying Geological Heritage in Large Territories: A Methodological Proposal Applied to Brazil
}

\author{
Flavia Fernanda de Lima • José B. Brilha • \\ Eduardo Salamuni
}

Received: 23 March 2010 /Accepted: 29 July 2010 /Published online: 22 August 2010

(C) Springer-Verlag 2010

\begin{abstract}
An adequate management of geological heritage by national and regional authorities presupposes the existence of a solid geosites inventory. Unfortunately, this is not the case for many countries. Most often, there is no national inventory at all or the method and criteria used to assess geosites was not adequate. This paper makes an overview of the strengths and weaknesses of the most common procedures to produce a geosite inventory and proposes a methodology particularly adapted for large territories such as Brazil. Nevertheless, this methodological approach can be easily adapted to any other geographical or geological setting, promoting the characterization and conservation of the world's geological heritage.
\end{abstract}

Keywords Geosites · Inventory · Geoconservation · Brazil

\section{Introduction}

In many countries, mainly outside Europe, wider knowledge about national geological heritage is limited and incomplete. In most cases, there is an inadequate geoconservation

\author{
F. F. de Lima $(\bowtie)$ \\ Geology Centre of the University of Porto, University of Minho, \\ Braga, Portugal \\ e-mail: flaferlima@yahoo.com.br \\ J. B. Brilha \\ Geology Centre of the University of Porto, University of Minho, \\ Braga, Portugal \\ e-mail: jbrilha@dct.uminho.pt \\ E. Salamuni \\ Mineropar and University Federal do Paraná, \\ Curitiba, Brazil \\ e-mail: esalamuni@yahoo.com.br
}

strategy undertaken by the national authority with responsibility on the implementation of nature conservation policies, or even no strategy at all (Dingwall 2000; Brilha 2002). The non-existence of a systematic inventory of the geological heritage and its adequate management may lead to the definitive destruction of geosites with scientific importance and many with international relevance.

The development of a geosites inventory should be the first step in any geoconservation strategy. The establishment of conservation and interpretation actions without having a complete geosites inventory is an improper start for any geoconservation project. For instance, in Portugal, in the mid-1990s five Natural Monuments, all related to dinosaur footprints, were created. Nevertheless, at that time, no study existed that could show if these five outcrops were, in fact, the most vulnerable or the most important geosites in the country. To create a protected area is, for most countries, a rather long and bureaucratic process. Therefore, this effort should only be applied to really important geosites and, to assess this importance, a solid national inventory is needed.

After the conclusion of a geosites inventory, the geoconservation strategy should proceed with the subsequent following stages: geosites characterisation, quantification of their relevance, protection according to the national legal framework, geosites conservation, valuation and interpretation and, finally, monitoring. There are very few countries where this strategy has been fully applied to the whole territory. In most cases, this complete approach is implemented just for a few geosites or a limited area due to the absence of a complete inventory for the country.

During the last 35 years, some international initiatives aiming to inventory the world's geological heritage have been implemented. The UNESCO's Convention concerning the Protection of the World Cultural and Natural Heritage, 
signed in Paris in 1972, was the first international effort to select sites of paramount world importance due to their natural characteristics. Some of the 180 properties presently inscribed in the World Heritage List for their natural properties were selected mainly for their geological significance (Dingwall et al. 2005; Migon 2009). In 1996, the International Union of Geological Sciences (IUGS) created the Global Geosites Project aiming the inventory of geosites with worldwide scientific importance Wimbledon (1996); Wimbledon et al. 1999). Unfortunately, IUGS closed this project in 2003 without reaching the main goals that were initially expected. In Europe, the Global Geosites Project was mainly conducted by ProGEO, the European Association for the Conservation of the Geological Heritage, created in 1992 to promote the conservation of European geosites and landscapes. In spite of the formal closure of the Global Geosites Project, ProGEO still promotes this task in European countries. For this reason, Europe is, by far, the continent where geosites inventories are more developed when compared with other regions of the world. The geoparks initiative (Zouros 2004; McKeever and Zouros 2005), which was started in 2000 in Europe, also contributes for the geosites inventory in these territories, although constituting an unsystematic inventory at the scale of a country.

At a national level and in what concerns the geosites inventory, the UK is probably the most advanced country in the world. The more intensive works have started during the middle of the 1950s (Wimbledon et al. 1995). Presently, more than 3,000 Geological Conservation Review sites with geological relevance are registered and protected as Sites of Special Scientific Interest under the law. Spain is another country that started in 1978 the national geosites inventory (Carcavilla Urquí et al. 2007; Carcavilla et al. 2009). Today, through compilation of regional data, Spain has identified 144 Global Geosites (of national and international status) representing 20 geological frameworks with international relevance were identified. The inventory of geosites with national relevance is in progress, under the leadership of the Spanish Geological Survey. These countries are just two examples of the effort is being done in Europe.

Mainly supported by the work done by one of the authors (Lima 2008), this paper intends to make a state-ofthe-art analysis about the methodologies for geosites inventorying and to propose its application to Brazil, as an example of a very large country. The first Brazilian attempt at a national inventory was registered in 1993 when the National Department of Mineral Production collaborated with UNESCO for inventorying some sites to be included in the World Heritage List. Nevertheless, only in 1997 was a more effective work started, aimed at inventorying the national geological heritage, following the creation of the Brazilian Commission of Geological and
Palaeobiological Sites-SIGEP (Schobbenhaus et al. 2002). Up to the present, about 100 sites have been identified and characterized from a scientific point of view. At the same time, the Brazilian Geological Survey (CPRM) is carrying out an initiative related to the creation of geoparks and the geotouristic use of some geosites, also in connection with SIGEP. As Brazil is a federation composed by 26 states, in some of them the respective regional Geological Survey is promoting the inventory of geosites, but mainly for geotouristic purposes. The two best examples so far are the project "Geological Trails in the Rio de Janeiro State" (Schmitt et al. 2004) supported by the Rio de Janeiro Geological Survey-DRM and the project "Geological and Palaeontological Sites in the Paraná State" (Piekarz and Liccardo 2006) based on work of the Paraná Geological Survey-MINEROPAR.

\section{General Methodologies for the Geosites Inventory}

Any geoconservation activity presumes the existence of a geosites inventory. From the simplest one carried out on very small areas with few geosites to complex geosites inventories for a whole country or continent with thousands of geosites, the main purpose is always the same: to identify geoheritage occurrences with high scientific, pedagogical or touristic relevance. The geoconservationist literature is abundant in examples of geosites inventories under multiple circumstances (for instance: Lapo et al. 1993; Wimbledon et al. 1995; Grandgirard 1995; Grandgirard 1996); Grandgirard 1999; Alexandrowicz and Kozlowski 1999; Parkes and Morris 1999; Karpunin 1999; Wimbledon et al. 1999; Serjani et al. 2003; García-Cortés and Fernández-Gianotti 2005; Brilha 2005; Pereira 2006; White and Mitchell, 2006; De Wever et al. 2006; Garcia-Cortéz and Carcavilla Urquí 2009. Nevertheless, one should note that, very often, the criteria used to select geosites for a certain inventory are not adequately explained or are even absent. A detailed analysis of all these works allowed us to define some strengths and weaknesses of the different inventory methods:

\section{Strengths}

Participative Activities The majority of the geosites inventorying methods are based on the published information and data provided by experts on the geology of the area (mainly geologists that have conducted geological mapping or research activities). This procedure allows to save time and resources and is particularly important when the area under study is geographically vast. Quite often, the selection of geosites with the consensus of experts, based on the Delphi methodology (Linstone and Turoff 1975), is considered a guarantee of a good inventory method. 
Criteria for Geosites Selection There is an extensive set of criteria normally used to identify potential geosites, which allows the comparison between geosites from different locations. Among the most usual criteria are: representativeness, rarity, possible use as a model to illustrate geological processes, diversity of geological elements, integrity, scientific value, and association with diverse geological elements.

Definition of Geological Frameworks Unfortunately, not all inventory methods are based on the definition of geological frameworks, a methodology proposed by ProGEO and used since the IUGS's Global Geosites Project. However, this is the methodology recommended for the inventorying of geosites with scientific value in large areas like countries or continents.

\section{Weaknesses}

Inventory Objective As already mentioned, many times the inventories are not so well done just because the inadequate definition of its main objective, leading to the use of unbalanced criteria. For instance, if the inventory intends to identify geosites with scientific relevance, the criterion "accessibility" should not be considered, due to its irrelevance to assess the scientific value of a geosite.

Novelty of the Subject As geoconservation and geological heritage are quite new subjects, for most of the countries there is no appropriate legislation or official institution to support a national geosites inventory. In addition, in most countries (mainly outside Europe) the nature conservation and geoscience communities do not consider geoconservation activities as an important and relevant work for society.

\section{A Proposal for Inventorying the Brazilian Geological Heritage}

Taking into account that each country should know and manage its own geological heritage, a proposal for the Brazilian geosites inventory has been proposed by Lima (2008). However, before undertaking such an inventory in Brazil it is necessary to be aware of several obstacles that should not be underestimated: (1) huge size of the country (about 8.5 million square kilometres); (2) incomplete geological knowledge for vast regions of the country (about $40 \%$ of the country is occupied by the Amazonian biome); (3) limited number of geologists and financial resources, considering the vast area of the country; and (4) low level of awareness in the geoscience community of geoconservation issues.

In order to overcome the problem of the size of the country, it is recommended that each one of the 26 states should be responsible for its own regional inventory. When these regional inventories are concluded, a national inventory can be built up, based on the same methodologies that European countries are using to create a continental inventory (for example, Satkunas et al. 2004; Tchoumatchenco 2004). For each state of Brazil, it is recommended that the top coordination of the regional inventory should be assumed by the State Geological Survey or, when such institution does not exist, by the Geological Survey of Brazil (CPRM).

The proposal for the Brazilian geosites inventory is comprised of the following successive steps: definition of the main aims; creation of working groups; literature review; definition and characterization of geological frameworks; identification of representative geosites and, finally, geosites characterization. It may be mentioned that, with appropriate adjustments, this methodology can be easily applied to other countries.

\section{Aim Definition}

A geosite inventory should always be focused on a clear objective to guarantee that the geosite selection occurs under the same criteria. In order to define this aim, four issues must be considered: the topic, the value, the scale, and the use. The topic is the subject or theme to be inventoried. For instance, the geological heritage (as a whole), the palaeontological heritage, the geomorphological heritage, a geological context or a geological framework. The value can be scientific, pedagogical, touristic, cultural, among others, and it is related closely to the use. The scale refers to the geographical area where the inventorying will occur (a natural park, a municipality, a state, a country, a continent, etc.). Finally, the use is related to the purpose of the inventoried geosites, for instance, to be the support for a national geoconservation strategy, to develop a geotouristic project, to promote the local geodiversity, etc.

Taking into account these issues, the aims of the present proposal for the Brazilian geosites inventory is to identify, select and characterize the geological heritage with high scientific value in each administrative state, as a way of supporting state and national geoconservation initiatives.

\section{Working Groups}

In order to achieve the defined aims, the Geological Survey (State or National) must promote the creation of three types of working groups that will work in a coordinate manner throughout the inventorying process: 
Coordination Committee Made up of geologists and other staff of the Geological Survey. This committee manages all activities, namely the definition of the suitable methodology and the creation of the Scientific Committee, the establishment of the timeline, and the organization and storage of all information and data produced during the inventory.

Scientific Committee Formed by geologists with scientific knowledge of the area to be inventoried. This committee creates and coordinates the Groups of Experts and receives and manages the scientific data produced by these groups. It is also responsible for the literature review (see "Literature Review").

Groups of Experts Composed by geoscientists representing different geosciences domains and expertises, including stratigraphers, geographers, geomorphologists, palaeontologists, etc. These groups should be formed only after the definition of the geological frameworks in order to find the most suitable experts.

\section{Literature Review}

The next step of the geosites inventory is the literature review which may supply relevant data for the inventory, such as doctorate and master theses, scientific papers and reports, geological maps, logs descriptions, etc. This review will assess the type of data already available, and the data that needs to be obtained during fieldwork. The review will also be useful for the definition of the geological frameworks that will support the inventory.

\section{Definition of Geological Frameworks}

For large territories, it is not possible to make a geosites inventory based on systematic fieldwork. To overcome this impossibility, ProGEO proposed some years ago the implementation of an inventory based on the definition of geological frameworks (Wimbledon 1996; Wimbledon et al. 1999, Gonggrijp 2000). The setting of these geological frameworks is a way to organize all geological information for the territory and to facilitate the subsequent identification of geosites representative for each framework. There are three main tendencies in the definition of geological frameworks: (1) by geological domains such as palaeontology, stratigraphy, geomorphology, mineralogy, etc.; (2) based on the geological timescale such as Archean, Proterozoic, Phanerozoic, etc.; and (3) by national/regional geological contexts such as Paraná Basin, Mantiqueira Province, etc.

For the inventory of Brazil and correspond geological heritage, the authors propose the use of the concept of structural provinces as defined by Almeida et al. (1977) and
Bizzi et al. (2003). These provinces allow the geological subdivision of the Brazilian territory and correspond to natural regions with specific stratigraphical, tectonic, magmatic, and metamorphic patterns. The structural provinces occur independently of administrative borders and therefore they are also suitable to compare inventories carried on in different states. To facilitate the inventory, each state may use sub-provinces.

All geological frameworks must be described taking into account their geographical distribution and geological specificity.

Geosite Identification

The geosites identification should follow the definition of geological frameworks. For each framework, the most representative geosites must be selected, according to the scientific knowledge and the opinion of the Groups of Experts. Selection based on well-defined criteria should take into consideration the aim of the inventory. For the Brazilian proposal, where the aim is to identify geosites with scientific value, three simple criteria were selected:

1. Representativeness - concerning the appropriateness of the geosite to illustrate a geological process or feature which brings a meaningful contribution to the understanding of the geological topic, process or feature;

2. Integrity-related with the conservation status and conservability of the geosites, taking into account both natural events and human action;

3. Scientific relevance - based on the existence of scientific data already published.

The proper number of geosites for each geological framework is not easy to define. On one hand, if it is too low there is the risk of these geosites not being fully representative of the framework; on the other hand, if it is too high, it will be difficult to manage all sites considering the total number of geological frameworks. In order to avoid the repetition of identical geosites for each framework, which is a tendency quite common for the experts' groups, the following criteria (Wimbledon et al. 1995) may be applied in sequence, giving preference to geosites that:

- Present the most complete and well-preserved record;

- Present the lower vulnerability;

- Have been studied in detail and have a long history of research;

- Present an assemblage of related features or interests.

\section{Characterization of Geosites}

For each geosite, a detailed description much be completed, including a general and geological characterization. All data 
Table 1 Criteria used to assess the potential educational use of geosites (modified from Junta de Andalucía 2002)

Criteria

Points

Representativeness

Best example representing a geological content at national level 4

Best example representing a geological content at state level 3

Best example representing a geological content at regional level 2

Best example representing a geological content at local level $\quad 1$

Quality of the exposure

Easily observed in totality

Some geological aspects are difficult to observe

The main geological aspects are difficult to observe

The main geological aspects are impossible to observe

Diversity at the state level

The geosite has 3 types of geological contents (stratigraphical, palaeontological, geomorphological, etc.) and it is representative for all

The geosite has 3 types of contents but it is not representative 3 for all

The geosite has 2 types of contents and is representative for both 2

The geosite has 2 types of contents but it is only representative 1 for one

Educational potential

The geosite illustrates geological aspects useful for all the 4 educational system

The geosite illustrates geological aspects only useful for fundamental and medium levels

The geosite illustrates geological aspects only useful for medium level

The geosite illustrates geological aspects only useful for university level

Logistics

There are lodging and restaurants for groups of 50 people in less than $15 \mathrm{~km}$

There are lodging and restaurants for groups of 50 people in less than $50 \mathrm{~km}$

There are lodging and restaurants for groups of 50 people in less than $100 \mathrm{~km}$

There are lodging and restaurants only for groups of 25 people 1 in less than $50 \mathrm{~km}$

Inhabitants within $25 \mathrm{~km}$

More than 1.5 million inhabitants

Between 500 thousand and 1.5 million inhabitants

Between 150 thousand and 500 thousand inhabitants

Between 50 thousand and 150 thousand inhabitants

Accessibility

Direct access by asphalted road with bus parking

Direct access by asphalted road

Direct access by unpaved road

No direct access but the geosite is located less than $1 \mathrm{~km}$ from a paved road

Vulnerability caused by human activities

No risk of damage

Possible risk affecting secondary geological aspects

Possible risk affecting main geological aspects

Possible risk affecting all geological aspects

Association with other values (ecological and/or cultural)

Presence of several ecological and cultural values within $2 \mathrm{~km}$

3

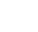

Table 1 (continued)

Criteria

Points

Presence of several ecological and cultural values within $5 \mathrm{~km} \quad 3$

Presence of one ecological and one cultural value within $5 \mathrm{~km} \quad 2$

Presence of only one ecological or cultural value within $5 \mathrm{~km} \quad 1$

Monumentality

The geosite is usually used in touristic iconography in national 4 or state levels

The geosite is sometimes used in touristic iconography in 3 national or state levels

The geosite is usually used in touristic iconography in regional or 2 local levels

The geosite is sometimes used in touristic iconography in regional or local levels

should be uploaded into a database, which will constitute the most important source of information of the inventory.

\section{General Characterization}

The general characterization of geosites aims at the collection of a set of wide-ranging data, namely:

- Geosite identification: name of the geosite; date; identification of the proponent.

- Location: geographical identification and references; GPS coordinates.

- Administrative status: identification of the owner (public or private) of the land where the geosite is located.

- Legal protection: if the geosite has already some kind of direct or indirect protection.

- Accessibility: description of the access routes to the geosite; their type and quality.

- Vulnerability: identification of natural and human processes that might affect the geosite (presently or in the near future).

\section{Geological Characterization}

The geological characterization describes each geosite and justifies its inclusion in the inventory. This characterization should include:

Geological Framework Identification of the geological framework in which the geosites are included (one geosite may represent more than one framework).

Geosite Description Size; type of exposition (natural or man-made); integrity.

Geological Content Brief description of the geological aspects that justify the importance of the geosite; main 
Table 2 Criteria used to assess the potential touristic use of geosites (modified from Junta de Andalucía 2002)

Criteria
Quality of the exposure
Easily observed in totality
Some geological aspects are difficult to observe
The main geological aspects are difficult to observe
The main geological aspects are impossible to observe
Logistics
There are lodging and restaurants for groups of 50 people in
less than $15 \mathrm{~km}$
There are lodging and restaurants for groups of 50 people in
less than $50 \mathrm{~km}$
There are lodging and restaurants for groups of 50 people in
less than $100 \mathrm{~km}$
There are lodging and restaurants only for groups of 25
people in less than $50 \mathrm{~km}$
Inhabitants within $25 \mathrm{~km}$

More than 1.5 million inhabitants

Between 500 thousand and 1.5 million inhabitants

Between 150 thousand and 500 thousand inhabitants

Between 50 thousand and 150 thousand inhabitants

Accessibility

Direct access by asphalted road with bus parking

Direct access by asphalted road

Direct access by unpaved road

No direct access but the geosite is located less than $1 \mathrm{~km}$ from a paved road

Vulnerability caused by human activities

No risk of damage

Possible risk affecting secondary geological aspects

Possible risk affecting main geological aspects

Possible risk affecting all geological aspects

Association with other values (ecological and/or cultural)

Presence of several ecological and cultural values within $2 \mathrm{~km}$

Presence of several ecological and cultural values within $5 \mathrm{~km}$

Presence of one ecological and one cultural value within $5 \mathrm{~km}$

Presence of only one ecological or cultural value within $5 \mathrm{~km}$

Monumentality

The geosite is usually used in touristic iconography in national or state levels

The geosite is sometimes used in touristic iconography in national or state levels

The geosite is usually used in touristic iconography in regional or local levels

The geosite is sometimes used in touristic iconography in regional or local levels

Recreational potential

The geosite easily illustrates geological aspects to the general public

The geosite easily illustrates geological aspects to the public with some geological background

The geosite easily illustrates geological aspects to the public with solid geological background
Table 2 (continued)

Criteria

Points

The geosite easily illustrates geological aspects but only to 1 experts

Social setting

The region has higher socio-economic indicators in relation 4 with the state and national average

The region has higher socio-economic indicators in relation 3 with the state average

The region has identical socio-economic indicators in relation with the state average

The region has lower socio-economic indicators in relation 1 with the state average

Proximity to recreational facilities

There are recreational facilities within $5 \mathrm{~km} \quad 4$

There are recreational facilities within $10 \mathrm{~km} \quad 3$

There are recreational facilities within $15 \mathrm{~km} \quad 2$

There are recreational facilities within $20 \mathrm{~km} \quad 1$

geological contents (palaeontogical, stratigraphical, tectonic, geomorphological, etc.)

Illustrations Excerpts of topographical and geological maps; geological sketches; pictures.

References Literature references demonstrating the scientific value of the geosite.

Observations Other relevant data important to characterize the geosite.

\section{Additional Characterization}

The general and geological characterizations are enough to achieve the aim expressed for the Brazilian inventory of geosites. However, as these geosites will be used in further steps as part of wider geoconservation strategy, it is convenient to enlarge the characterization and include the assessment of the potential use of geosites (apart from the scientific one) and the risk of degradation as a result of these possible uses. In order to save time and efforts, the additional assessment should be done at the same time as the general and geological assessment by the same team.

To assess the potential educational and touristic uses of a geosite, several criteria should be assessed, each one divided into four sub-criteria and evaluated on a scale of one to four points (Tables 1 and 2). The use of a numerical approach decreases the subjectivity of an assessment procedure and allows the establishment of a ranking based on the final scores. For instance, a geosite ranging from 301 
Table 3 Criteria used to evaluate the educational and touristic potential uses of a geosite and corresponding weights to calculate the final assessment

\begin{tabular}{lll}
\hline Criteria & $\begin{array}{l}\text { Weight for } \\
\text { educational use }\end{array}$ & $\begin{array}{l}\text { Weight for } \\
\text { touristic use }\end{array}$ \\
\hline $\begin{array}{l}\text { Representativeness } \\
\text { Quality of the exposure }\end{array}$ & 5 & - \\
$\begin{array}{l}\text { Diversity at the state level } \\
\text { Educational potential }\end{array}$ & 5 & 5 \\
Logistics & 30 & - \\
Inhabitants around 25 km & 15 & - \\
Accessibility & 10 & 10 \\
Vulnerability caused by human & 5 & 5 \\
$\quad$ activities & 5 & 10 \\
Association with other values & 5 & 15 \\
$\quad$ ecological and/or cultural) & 5 & 10 \\
Monumentality & 5 & 15 \\
Recreational potential & - & 20 \\
Social setting & - & 5 \\
Proximity to recreational facilities & - & 5 \\
Total & 100 & 100 \\
\hline
\end{tabular}

A high final value means a higher appropriateness for educational and/ or touristic uses (modified from Junta de Andalucía 2002)

to 400 points for the valuation of a touristic use is considered to have a high potential.

For both types of use, there are similar criteria: for instance, quality of exposure, logistics or accessibility. Nevertheless, for the final assessment, these criteria have been given different weights in order to better evaluate the potential use (Table 3). As an example, one may refer the monumentality criterion that is very important to evaluate the touristic use (weight 15) but it is not so important to assess the educational potential of a geosite (weight 5).

The additional assessment should also assess the risk of degradation of each geosite, incidental to its possible use. The methodology is similar with to the one proposed for the assessment of the potential educational and touristic uses (Table 4). The evaluation of the risk of degradation is very important for management purposes and to define priorities for an action plan. Not all inventoried geosites need urgent management actions and hence the available resources should be prioritized where they are most needed.

\section{Concluding the Geosites Inventory}

Finishing the assessment of geosites, the state inventory is almost concluded. All data supplied by the Groups of Experts to the Scientific Committee should be verified in order to proceed to the database compilation stage. The Scientific Committee, as it has an overview of all the available data, has also the responsibility of confirming the quantitative assess- ment results that have been obtained on the potential use and risk of degradation.

The Coordination Committee of the geosites inventory for a certain state now has the information of how many geosites with scientific relevance occur their state, which also have educational and/or touristic potential and which need a management plan. The most relevant geosites to understand the state's geological evolution should be protected in accordance with the state's legal framework, and those with national importance should be proposed for protection under nature conservation legislation at the federal level.

Nevertheless, the Brazilian inventory of geosites is not yet concluded. The geological heritage of each state is now well known, but the national inventory needs yet to be

Table 4 Criteria used to evaluate the risk of degradation of a geosite and corresponding weights

\begin{tabular}{|c|c|c|}
\hline Criteria & Points & Weigh \\
\hline $\begin{array}{l}\text { Vulnerability caused by natural or human factors } \\
\text { Possible risk affecting all geological aspects }\end{array}$ & 4 & 35 \\
\hline Possible risk affecting main geological aspects & 3 & \\
\hline Possible risk affecting secondary geological aspects & 2 & \\
\hline No risk of damage & 1 & \\
\hline $\begin{array}{l}\text { Proximity to potential damaging areas (mining, } \\
\text { industries, recreation, urban, ...) }\end{array}$ & & 20 \\
\hline $\begin{array}{l}\text { Geosite located within } 500 \mathrm{~m} \text { of a potential } \\
\text { damaging area }\end{array}$ & 4 & \\
\hline $\begin{array}{l}\text { Geosite located within } 1 \mathrm{~km} \text { of a potential damaging } \\
\text { area }\end{array}$ & 3 & \\
\hline $\begin{array}{l}\text { Geosite located within } 2 \mathrm{~km} \text { of a potential damaging } \\
\text { area }\end{array}$ & 2 & \\
\hline $\begin{array}{l}\text { Geosite located within } 5 \mathrm{~km} \text { of a potential damaging } \\
\text { area }\end{array}$ & 1 & \\
\hline Present protection status & & 20 \\
\hline $\begin{array}{l}\text { Geosite with no legal protection and no access } \\
\text { control }\end{array}$ & 4 & \\
\hline $\begin{array}{l}\text { Geosite with no legal protection but with access } \\
\text { control }\end{array}$ & 3 & \\
\hline Geosite with legal protection but no access control & 2 & \\
\hline Geosite with legal protection and access control & 1 & \\
\hline Accessibility & & 15 \\
\hline Direct access by asphalted road with bus parking & 4 & \\
\hline Direct access by asphalted road & 3 & \\
\hline Direct access by unpaved road & 2 & \\
\hline $\begin{array}{l}\text { No direct access but the geosite is located less } \\
\text { than } 1 \mathrm{~km} \text { from a paved road }\end{array}$ & 1 & \\
\hline Inhabitants within $25 \mathrm{~km}$ & & 10 \\
\hline More than 1.5 million inhabitants & 4 & \\
\hline Between 500 thousand and 1.5 million inhabitants & 3 & \\
\hline $\begin{array}{l}\text { Between } 150 \text { thousand and } 500 \text { thousand } \\
\text { inhabitants }\end{array}$ & 2 & \\
\hline Between 50 thousand and 150 thousand inhabitants & 1 & \\
\hline
\end{tabular}

A high final value means a higher risk of degradation, which denotes a greater need of a management plan (modified from Junta de Andalucía 2002) 
produced with the comparison of geosites across the country that belongs to the same geological framework. That is why it is so important that each State Coordination Committee works and uses the same type of geological frameworks, as emphasized in "Definition of Geological Frameworks". With the purpose of promoting the national inventory, two more working groups must be created:

- National Coordination Committee: sponsored by the Brazilian Geological Survey (CPRM), has as its main tasks the collection and assessment of data supplied by the National Scientific Committee.

- National Scientific Committee: formed by one delegate of each State Scientific Committee, has the responsibility of making a comparison between geosites of different states, but representative of the same geological framework. This committee will also define the national geological frameworks based on the combination and selection of state frameworks.

Finally, the geosites that comprise the national inventory should be protected under available legislation, as they are part of the rich Brazilian natural heritage and testimony of part of the Earth's geological history.

\section{Final Considerations}

In many countries, geosites are at risk of degradation or even total loss due to an inadequate management. Most often, the national authorities are not even aware of this threat to the natural environment because there is no systematic inventory of the national geological heritage. Countries with very extensive land areas, like Brazil, have more difficulties in completing their national inventory, due to the lack of a general geological knowledge and to a shortage of geologists prepared for such a task.

A literature review about the inventory methods used in several countries allowed the selection of several key issues that were used as a starting point for the methodology proposed in this paper: the existence of participative activities; the establishment of detailed criteria for the geosite selection; and the definition of geological frameworks.

This proposal for the Brazilian geosite inventory involves the following successive steps: definition of the main aims; creation of working groups; literature review; definition and characterization of geological frameworks; identification of representative geosites and, geosite characterization. A numerical approach to assess the potential use of the selected geosite (beside the scientific one) and the risk of degradation is also proposed to finalise the geosites characterisation stage. These quantitative procedures are very useful to compare geosites selected under the same methodology and during the same inventory process.
In addition, they allow the establishment of a ranked geosite list, which is most useful for management purposes.

In spite of being suitable to be applied to large territories, the methodological proposal expressed in this paper can be easily adapted for other situations. It can help to set up geosite inventories all over the world, particularly in those countries where the knowledge about the geological heritage with national relevance is deficient.

Acknowledgement This work was partially sponsored by the Foundation for Science and Technology (Portugal) and by Programme Alßan (High Level Scholarship Programme of the European Union) under the scope of F.F. Lima's master dissertation. The authors are grateful to Virginio Mantesso Neto for revising the English version of the manuscript.

\section{References}

Alexandrowicz Z, Kozlowski S (1999) From selected geosites to geodiversity conservation-Polish example of modern framework. In: Barettino D, Vallejo M, Gallego E (eds) Towards the balanced management and conservation of the geological heritage in the new millennium. Sociedad Geológica de España, Madrid, Spain, pp 40-44

Almeida FFM, Hasui Y, Neves BBB, Fuck RA (1977) Províncias estruturais brasileiras. In: Atas Simpósio de Geologia do Nordeste. SBG, Campina Grande, Brazil, pp 363-391

Bizzi LA, Schobbenhaus C, Vidotti RM, Gonçalves JH (Org) (2003) Geologia, tectônica e recursos minerais do Brasil: texto, mapas \& SIG. Brasília: CPRM-Serviço Geológico do Brasil. p. 692

Brilha J (2002) Geoconservation and protected areas. Environ Conserv 29(3):273-276

Brilha J (2005) Património Geológico e Geoconservação: a Conservação da Natureza na sua Vertente Geológica. Palimage Editores, Braga, Portugal, p 190

Carcavilla L, Durán JJ, García-Cortés A, López-Martínez J (2009) Geological heritage and geoconservation in Spain: Past, Present, and Future. Geoheritage 1(2-4):75-91

Carcavilla Urquí L, López Martinez J, Durán Valsero JJ (2007) Patrimonio Geológico y Geodiversidad: investigación, conservación, gestión y relación con los espacios naturales protegidos. Instituto Geológico y Minero de España, Madrid, Spain, p 360

Junta de Andalucía (2002) Propuesta de estrategia andaluza para la protección de la Geodiversidad. Consejería de Medio Ambiente/ Departamento de Estratigrafía y Paleontología Universidad de Granada. p. 105

De Wever P, Le Nechet Y, Cornee A (2006) Vade-mecum pour l'inventaire du patrimoine géologique national. Mém. H. S. Soc. Géol. Paris, France, 12. p. 162.

Dingwall P (2000) Legislación y convenios internacionales: la integración del Patrimonio Geológico en las políticas de conservación del medio natural. In: Barettino D, Wimbledon WAP, Gallego YE (eds) Patrimonio Geológico: Conservación y Gestión. ITGE, Madrid, Spain, pp 15-29

Dingwall P, Weighell T, Badman T (2005) Geological World Heritage: A global framework. A Contribution to the Global Theme Study of World Heritage Natural Sites. IUCN, Gland, Switzerland, p 51

García-Cortés A, Fernández-Gianotti J (2005) Estrategia del Instituto Geológico y Minero de España para el estudio y protección del Patrimonio Geológico y la Geodiversidad. In: Lamolda MA (ed) 
Geociencias. Recursos y Patrimonios Geológicos, Instituto Geológico y Minero de España, Madrid, pp 59-72

Garcia-Cortéz A, Carcavilla Urquí L (2009) Documento metodológico para la elaboración del inventario español de lugares de interés geológico (IELIG), version 12. Instituto Geológico y Minero de España, Madrid, p 61

Gonggrijp GP (2000) Patrimonio Geológico: Conservación y Gestión. In: Barettino D, Wimbledon WAP, Gallego YE (eds) Planificación y Gestión para la Geoconservación. ITGE, Madrid, Spain, pp 31-49

Grandgirard V (1995) Méthode pour la réalisation d'un inventaire de géotopes géomorphologiques. Cahiers de l'Institut de Géographie de l'Université de Fribourg, Ukpik, 10., pp 121-137

Grandgirard V (1996) Gestion du patrimoine naturel, l'inventaire des géotopes géomorphologiques du canton de Fribourg. Rapports de Recherches de l'Institut deGéographie de l'Université de Fribourg, Ukpik, 8., pp 181-195

Grandgirard V (1999) Switzerland - the inventory of geotopes of national significance. In: Barettino D, Vallejo M, Gallego E (eds) Towards the balanced management and conservation of the geological heritage in the new millenium. Sociedad Geológica de España, Madrid, Spain, pp 234-236

Karpunin AM (1999) Problems of selection and grading of geological monuments (Geosites of Russia). In: Barettino D, Vallejo M, Gallego E (eds) Towards the balanced management and conservation of the geological heritage in the new millenium. Sociedad Geológica de España, Madrid, Spain, pp 145-147

Lapo AV, Davydov VI, Pashkevich NG, Petrov VV, Vdovets MS (1993) Methodic principles of study of geological monuments of nature in Russia. Stratigr Geol Correl I(6):636-644

Lima FF (2008) Proposta metodológica para a inventariação do Património Geológico Brasileiro. Tese de Mestrado. Universidade do Minho, Braga, Portugal, p 94

Linstone HA, Turoff M (eds) (1975) The Delphi Method - Techniques and Applications. Reading, Mass.:. Addison-Wesley Pub. Co, Advanced Book Program, p 620

McKeever PJ, Zouros N (2005) Geoparks: Celebrating Earth heritage, sustaining local communities. Episodes 28(4):274-278

Migon P (2009) Geomorphosites and the World Heritage List of UNESCO. In: Reynard E, Coratza P, Regolini-Bissig G (eds) Geomorphosites. Verlag Dr. Friedrich Pfeil, Munchen, pp 119-130

Parkes MA, Morris JH (1999) The Irish Geological Heritage Programme. In: Barettino D, Vallejo M, Gallego E (eds) Towards the balanced management and conservation of the geological heritage in the new millenium. Sociedad Geológica de España, Madrid, Spain, pp 60-64
Pereira P (2006) Património geomorfológico: conceptualização, avaliação e divulgação. Aplicação ao Parque Natural de Montesinho, Tese de Doutoramento, Universidade do Minho, Braga, Portugal, p 370

Piekarz GF, Liccardo A (2006) Programa Sítios Geológicos e Paleontológicos do Paraná-Situação Atual e Tendências. Anais XLIII Congresso Brasileiro de Geologia, Aracajú, Serjipe, p 89

Satkunas J, Mikulenas V, Lazauskiene J, Raudsep R, Taht K, Markots A, Lacis A (2004) Towards a Geosites framework in Northern Europe - a first attempt in the Baltic States. In: Parkes MA (ed) Natural and Cultural Landscapes - The Geological Foundation. Royal Irish Academy, Dublin, Ireland, pp 117-120

Schmitt RS, Tupinambá M, Valeriano C, Ragatky D, Mansur KLO (2004) Projeto Caminhos Geológicos-Divulgação Científica dos Monumentos Geológicos do Estado do Rio de Janeiro. Anais II Congresso Brasileiro de Extensão Universitária, Belo Horizonte, UFMG/Pró-Reitoria de Extensão

Schobbenhaus C, Campos DA, Queiroz ET, Winge M, Berbert-Born MLC (eds) (2002) Sítios Geológicos e Paleontológicos do Brasil. Brasília: DNPM/CPRM-Comissão Brasileira de Sítios Geológicos e Paleobiológicos (SIGEP), vol 1. p. 554

Serjani A, Neziraj A, Wimbledon WAP, Onuzi K, Hallaci H, Bushati S (2003) Geological heritage and geotourism in Albania. Tiranë, Dhjetor, $\mathrm{p} 132$

Tchoumatchenco P (2004) Ukraine Geosites frameworks for the Jurassic rocks in Bulgaria. In: Parkes MA (ed) Natural and Cultural Landscapes - the Geological Foundation. Royal Irish Academy, Dublin, Ireland, pp 97-100

White S, Mitchell M (2006) Geological heritage sites: a procedure and protocol for documentation and assessment. AESC2006. Melbourne, Australia, $\mathrm{p} 2$

Wimbledon WAP (1996) Geosites - a new conservation initiative. Episodes 19(3):87-88

Wimbledon WAP, Benton MJ, Bevins RE, Black GP, Bridgland DR, Cleal CJ, Cooper RG, May VJ (1995) The Development of a methodology for the selection of British Geological sites for geoconservation: Part 1. Mod Geol 20:159-202

Wimbledon WAP, Andersen S, Cleal, CJ, Cowie JW, Erikstad L, Gonggrijp GP, Johansson CE, Karis LO, Suominen V (1999) Geological World Heritage: GEOSITES - a global comparative site inventory to enable prioritisation for conservation. Memorie Descrittive della Carta Geologica d'Italia, vol. LIV: pp 45-60.

Zouros N (2004) The European Geoparks Network: geological heritage protection and local development. Episodes 27(3):165171 